\title{
Characterization of Morphology and Potential of Pineapple Genetic Resources in Peatland of Jambi Province
}

\author{
Desi Hernita1* $^{*}$ Eva Salvia1 and Julistia Bobihoe ${ }^{1}$
}

${ }_{1}^{1}$ Jambi Assessment Institute for Agriculture Technology, IAARD, Indonesia

*Corresponding author : desi_hernita@yahoo.com

\section{ARTICLE HISTORY}

$\begin{array}{ll}\text { Received } & : 11 \text { February } 2019 \\ \text { Revised } & : 18 \text { March } 2019 \\ \text { Accepted } & : 14 \text { April } 2019\end{array}$

KEYWORDS:

Pineapple

Peatland

Jambi Province

\begin{abstract}
Jambi Province has large peatlands (621,089 ha). Utilization of that land in agricultural sector will contribute in economic development of surrounding society. Tangkit and Paun Pineapple are plant genetic resource (PGR) that must be maintained and secured from extinction and erosion of genetic potential. This is because the real PGR continues to be utilized for the survival and welfare of the community. The research purpose was to know the morphological of PGR pineapple that have potential to grow, produce and adapt in peatland of Jambi Province. Survey method was used in this research and conducted in Tangkit Baru Village, Sungai Gelam District, Muaro Jambi Regency and Sungai Baung Village, Pengabuan District of Tanjung Jabung Barat Regency, Jambi Province in 2016 and 2017. The results showed that significant different were occurred between Tangkit and Paun pineapple in leaf morphology, flowers, fruit, harvesting age and production/ha. Production of Tangkit and Paun pineapple were 13.5 ton/ha and 9.1 - 13 ton/ha respectively. The leaves of Tangkit pineapple were prickly, meanwhile, Paun pineapple was not thorny; Fruit of Tangkit pineapple was round oval, and Paun pineapple cones-like with 3-4 times bigger in size than Tangkit pineapple (3.5 - $5 \mathrm{~kg}$ ). Paun Pineapple can only grow in peatland with $3 \mathrm{~m}$ depth while on shallow peat fruit production is not optimal Tangkit Pineapple grow and produce well on peatland with $\mathrm{pH} \leq 5.0$. Paun Pineapple also well adapted to low peatlands with elevation $0-30 \mathrm{~m}$ asl and soil $\mathrm{pH} 4.5-6.5$.
\end{abstract}

This is an open access article under the CC-BY-SA license.

\section{INTRODUCTION}

Pineapples is one of the national superior fruits and also contributes to foreign exchange. Indonesian pineapple production is quite large, in 2015 it reached 1.73 million tons. Indonesia is the third largest producer of pineapple for Southeast Asia after the Philippines and Thailand with a contribution of around 23\%. Almost all regions of Indonesia are pineapple producing areas because they are supported by a suitable tropical climate. However, the development of pineapple has not received serious attention because the underdeveloped use of superior varieties and cultivation techniques have not been optimal Indonesian pineapple production ranks third after bananas and mangoes (Pusdatim, 2016; Nindita, 2018).

The prospect of pineapple agribusiness is very bright and tends to increase both for the needs of fresh fruit as well as processed ingredients. The main part of the important economic value of pineapple plants is the fruit (Nofriati et al., 2016). Apart from being consumed in fresh form, pineapple can also be processed into various products such as juice, jam, syrup and chips. Pineapple fruit has an important meaning for fulfilling community nutrition and is one of the fruits that has many benefits with high nutrient content. Pineapple contains elements of water, sugar, organic acids, minerals, nitrogen, protein, bromelin and all vitamins in small amounts, except vitamin D (Hadiati and Indriyani, 2008). The nutritional content of pineapple is very beneficial for the health of the body and has properties for healing (Hossain et al, 2015). Bromelin is efficacious as an anti-inflammatory, helps soften food in the stomach, and inhibits the growth of cancer cells. The fiber content can facilitate defecation in patients with constipation. Pineapple shell can be processed into syrup or extracted liquid for animal feed, while fiber in leaves can be processed into paper and textiles (Hadiati and Indriyani, 2008).

Pineapple production in Jambi Province ranks 5th nationally after Lampung, North Sumatra, West Java and East Java with an average production in 2011-2015 of 146.1 tons or a contribution of $8.23 \%$. (Pusdatin, 2016). Jambi Province has two superior pineapple varieties 
which are genetic resources (PGR) on peat land, namely Tangkit pineapple and Paun pineapple, which located in Muaro Jambi District and West Tanjung Jabung Regency. Dwiyanto and Setiadi (2008) stated this PGR is one of the germplasm that must be maintained and secured from extinction and erosion of genetic potential. This is because the PGR in real terms has been and continues to be utilized for the survival and welfare of the community, both at the local, regional, national, and global levels.

Tangkit pineapple grow and produce well on peatland which soil $\mathrm{pH}$ was $\leq 5.0$, while Paun pineapple at soil $\mathrm{pH}$ was $4.5-6.5$. Both of these pineapple varieties adapted to lowlands with elevation of $0-30 \mathrm{~m}$ altitude of sea level. Tangkit pineapple grows well in 1-3 m peat depths (Hendri et al. 2017) while Paun pineapple can only grow in peatland with $3 \mathrm{~m}$ depth and more shallow peat fruit production is not optimal (Dispertan, 2010). Peatlands are part of swamps which throughout the year or over a long period of time are always waterlogged or flooded. Land that occupies a transitional position between land and water systems is called peat (Widjaya et. al., 1992) and Subagyo (1997). The results of the inventarisation and identification carried out by the Indonesian Center for Agricultural Land Resources Research and Development (ICALRRD), peatlands area in Jambi Province, 716,839 ha (including peat mineral soil). The peatland area of Muaro Jambi Regency was 30\% of the peatland area in Jambi Province and Tanjung Jabung Barat Regency 20\%. This research activity aimed to determine the morphological character of the Tangkit and Paun Pineapple PGR and its potential on the peatland of Jambi Province.

\section{MATERIALS AND METHODS}

The research was conducted in area of pineapple central production at Tangkit Baru Village, Sungai Gelam Subdistrict, Muaro Jambi Regency and Pengabuan District of Tanjung Jabung Barat Regency, Jambi Province in 2016 and 2017. The tools used are: stationery, calipers, camera, meter, ruler, label paper, plastic, cutter, scales. The method used is survey method and supported by primary and secondary data obtained from the field and literature studies.

\subsection{Morphological Characters of Tangkit Pineapple}

Tangkit pineapple varieties belong to the Queen group (yellow flesh) and generally consumed in fresh form. Tangkit Pineapple has hard leaves and the margin contain spines. Tangkit pineapple is an herbaceous plant, 100-110 $\mathrm{cm}$ tall, stem yellowish green (light green), canopy width 80-85 cm. A fully grown Tangkit pineapple has 45-50 leaves arranged in the form of a dense compact rossete (Dispertan, 2013). The older leaves are located at the base of the plant and the younger ones in the centre. Leaves are sword shaped (except for the ones at the tip) and taper toward the tip. The upper and lower surfaces of the leaf are covered with hairs that are more pronounced on the lower surface (Purseglove, 1972; Morton, 1987; Coppens d'Eeckenbrugge \& Leal 2001; Bartholomew et al., 2003 cit anonymous, 2018; Kurniadinata, 2018).

The leaf length of Tangkit pineapple $96-100 \mathrm{~cm}$, base leaf width $5,3-7,5 \mathrm{~cm}$, middle $6-6,5 \mathrm{~cm}$, and top $3,2-4,2 \mathrm{~cm}$. The color of the leaves on top of the base is green, middle and the tip of purplish leaves, while the lower leaves are whitish green (Dispertan, 2013).

The leaves enclose the stem up to two thirds of its circumference, are wide at the base and form a sheath around the stem. Due to the tendency to collect water at the base, the leaves are semi rigid, this feature may also provide aerial roots with water and nutriens (Bartholomew et al., 2003)

Flowers have 8 pieces of stamens and 1 pistil. Tangkit pineapple fruit with oval shape, length of fruit stalk 13-15 $\mathrm{cm}$. Fruit weight $1.3-1.5 \mathrm{~kg}, 20-25 \mathrm{~cm}$ long, $31.5 \mathrm{~cm}$ wide at the top, $34.5 \mathrm{~cm}$ wide at the middle and $35.5 \mathrm{~cm}$ wide at the base. The color of the fruit young is green, physiological ripe is yellowish green and ripe is yellow (Dispertan, 2013). The fruit eye is shallow notched, and more flat, large and round in shape when physiologically ripe. Other characteristics that show pineapple have been physiologically ripe and ready to be harvested are the crown of open fruit, fruit stems shrinking, the color of the base of the yellow fruit, the aroma of fruit begins to appear (Hadiati and Indriyani, 2008). The stage of development of flowers dan fruit Tangkit pineapple can be seen in Figure 1 and 2.

\section{RESULTS AND DISCUSSION}
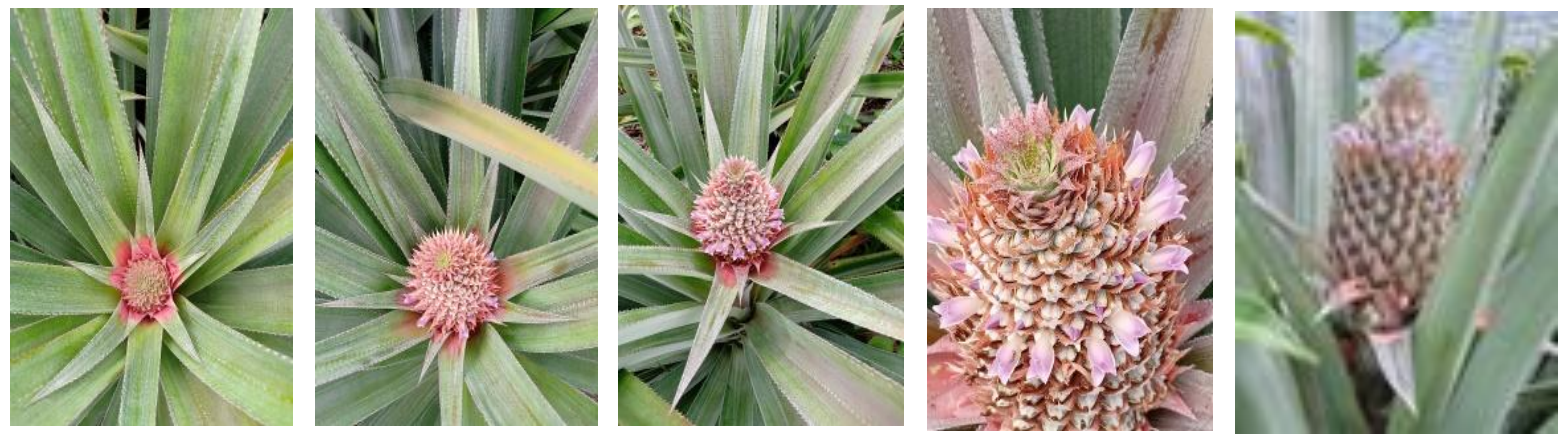

Figure 1. Stage of Flowers Development on Tangkit Pineapples 

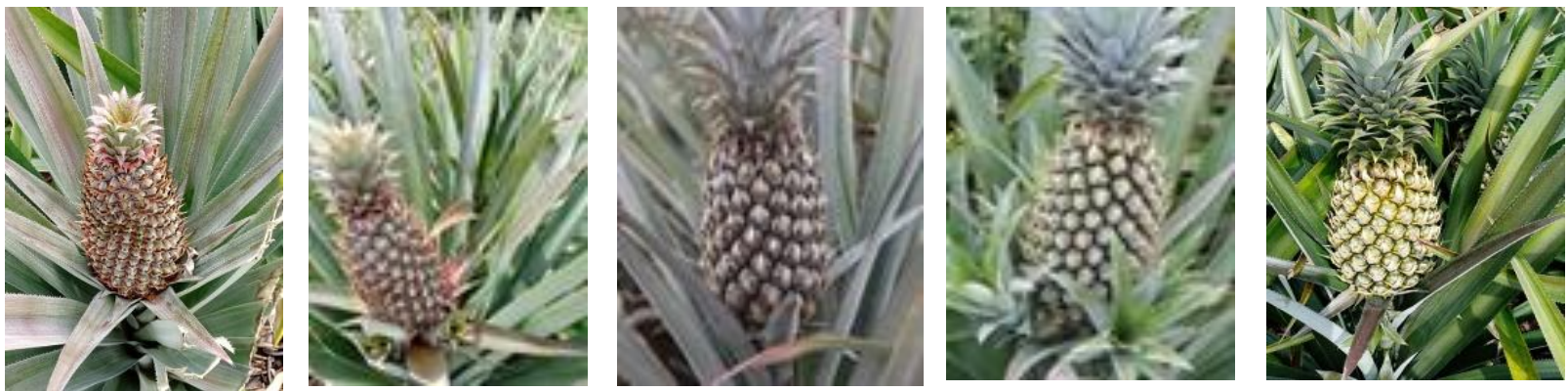

Figure 2. Stage of fruit development on Tangkit Pineapples

Tangkit Pineapple is a fruit plant that sweet-sour tastes, the texture of the flesh of fine fruit is slightly fibrous, the flesh color of yellow fruit and pith is yellowish white with a width of $3.0 \mathrm{~cm}$. Physiological ripe sugar levels $11.60 \%$ (Balitro, 2013) - 23, 13\% (Asni et al., 2004), and water content $84.97 \%$ (Dispertan, 2013). The summer fruit has a higher sugar level when compare to winter fruit. The content of vitamin C is $24.33 \%$, acidic content is $9.31 \%$, and carbohydrates are $2.01 \%$ (Asni et al., 2004). The weight per fruit is $1.3-1.5 \mathrm{~kg}$ and the fruit storability is 7 days after harvested at room temperature (Dispertan, 2013). Daily fruit productivity is an average 3000 pieces or 4.5 tons/ha. Productivity of Tangkit Pineapple in 2017 was 17, 34 tons/ha (Pemdes Tangkit Baru, 2018) or higher than the results of survey conducted in 2014 which was 13.50 tons/ha (Mukhlish, 2014).

\subsection{Morphological Characters of Paun Pineapple}

Paun pineapple is adaptive on peatlands with central areas of Sungai Baung Village Pengabuan District, Tanjung Jabung Barat Regency. This pineapple belongs to the smooth cayene group and generally used as canned fruit (Dispertan, 2010). Paun pineapple has softer leaves, the margin not spines, $100-110 \mathrm{~cm}$ tall, the stem is round, the color of the stem is green to dark green, the stem diameter is 6-7.5 cm, leaf length $80-85 \mathrm{~cm}$, base leaf width 7.2-9.1 $\mathrm{cm}$, middle 6-7.2 cm, top $4-5.7 \mathrm{~cm}$, number of leaves 128-140 sheets. The color of the upper leaves; the margin of green, the middle of the reddish purple and slightly starchy, while the color of the lower leaves is green and a lot of starchy.
The root system is primarily adventitious, typical of monocots (Purseglove 1972).The shoot weight determines the number of roots produced. Adventitious roots are prese on the stem and grow in a distorted manner around the stem between the leaves. forming a tuft of fibrous roots near the base of the stem. Crowns present as leafy parts on the top of fruits produce more roots than shoots (Purseglove 1972; Bartholomew et a1. 2003). The crown, suckers, slips, butt and stumps are parts of th plant used in vegetative reproduction.

Flowers are reddish purple, the color of the crown is purple, the bottom is light purple, the number of crowns is 3 strands, the pistils are white and the stems are very young purple stamens and the stamens are yellow. The fruit is shaped almost like a cone (Dispertan, 2013).

Fruit weight 4-9 $\mathrm{kg}$ (Supriyanto et al., 2015), and can reach $12 \mathrm{~kg}$ (interview with farmers) fruit length 24-32 $\mathrm{cm}, 14-19 \mathrm{~cm}$ diameter at the base and 13-19 $\mathrm{cm}$ diameter at the middle, circumference of fruit $47-50 \mathrm{~cm}$ at the base, 41-46 circumference of fruit at the middle and 36-39 cm circumference of fruit at the top. The color of the fruit young is dark green, physiological ripe is yellowish green and ripe is yellow (Dispertan, 2013). Number of fruit eyes 160 - 175, large shape and deep notched. The stage of development of flowers to ripe fruit can be seen in Figure 3. Paun pineapple is a fruit plant that sweet-sour tastes. The flesh color of young fruit is white and yellow if ripe. The texture of the flesh is fine. The content of vitamin $\mathrm{C}$ is $25 \mathrm{mg} / 100 \mathrm{~g}$ acidic content is $4.65 \%$, water content $85.36 \%$, sugar levels $18.33 \%$ and fibrous content 0,50 gr/100 gr. The fruit storability is 9 days after harvested at room temperature. Productivity of Paun Pineapple 9.1 - 13 ton/ha (Dispertan, 2013).
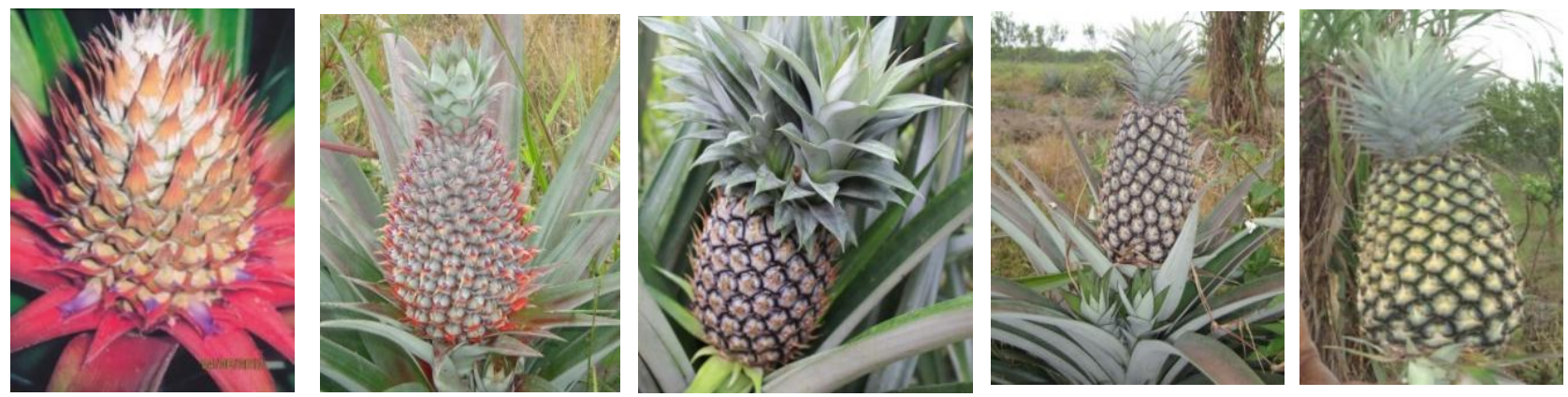

Figure 3. Stage of flowers to ripe fruit development on Paun Pineapples 
The stage of development the flower becomes fruit, the top of flower will form a tuft of small leaves, known as the crown that may be used for vegetative propagation. Crowns on Paun pineapple can amount to more than one, while in Tangkit pineapple there is one (Figure 3).

\subsection{Potential Development of Tangkit and Paun Pineapples}

Tangkit and Paun pineapple are local genetic resource from Jambi which has been released as national superior variety and adaptive on peatlands. Tangkit pineapple center in Tangkit Baru Village, Sungai Gelam District, Muaro Jambi Regency, Jambi Province. Tangkit pineapple was commodity that has great opportunity to be developed into qualified product, increasing economy value and people's main income. The village of Tangkit Baru has been designated as center for agro-politan and home industry (Yanti et al., 2015) . Tangkit pineapple, besides entering the domestic market, has been exported to Singapore and Malaysia (Anonymous, 2013).

The potential of Tangkit pineapple was consumed fresh and processed product. Processed products which have been developed in Tangkit Baru Village were pineapple dodol, pineapple fried, jam and pineapple chips. Processed products which will be developed was velva (fozen dessert) products. Velva is more nutritious and can be used to increase the diversity of pineapple processed products in Tangkit Baru Village in an effort to increase revenue (Lavlinesia et al., 2016).

Tangkit pineapple which is planted in new areas by using good technology can be produced $1.5-3 \mathrm{~kg} /$ fruit. Tangkit pineapple could grow and produc well on peatlands with of $\mathrm{pH} \leq 5.0$ (Hernita dan Yanti, 2018). Land area of Tangkit pineapple in Tangkit Baru Village is 1,249 ha, production of 144.869 ton/tahun (BPS Provinsi Jambi, 2013). The production of Tangkit pineapple in 2018 is 10,101 tons/year or productivity 162,92 tons/ha/year or average 32,792 fruit/ha/year (Asmaida and Zarkasih, 2018). The average production of pineapple per day is 20,000 fruit and productivity13.5-17.34 ton/ha (Mukhlish et al. 2014; Pemdes Tangkit Baru, 2018). The price of pineapple is Rp. 1,400,- to Rp. 6,000,-/fruit (Mukhlish et al. 2014). The results of research by Yanti et al. (2017) showed that the analysis of pineapple farming was beneficial, with $\mathrm{R} / \mathrm{C}$ ratio is 2.72 . This shows that pineapple farming is beneficial and can be developed in Jambi Province.

The adaptation and maximum production of Paun pineapple is with peat depth of $\pm 3,0-30 \mathrm{~m}$, altitude of sea level and soil pH 4.5-6.5. The peatland (while not cultivated) is one of the potentials for cultivating Paun pineapple in Tanjung Jabung Barat Regency (Hernita and Salvia, 2018). The area of Paun pineapple is currently around 8 ha in Sungai Baung Village, Pengabuan District and development in 2018 Tanjung Pasir Village, Kuala Betara District of 0.25 ha or 1,000 plants (information from Food Crop and Horticulture Services of Tanjung Jabung Barat Regency). The area of peatland in Tanjung Jabung Barat Regency is $32.72 \%$ of the total area or
163,100 ha (BPS Kabupaten Tanjung Jabung Barat, 2018). This is potential for the development of Paun pineapple.

The extensive peatlands in Jambi Province (716,839 ha) have been potential for the development of pineapple. Sopiawati et al. (2013) and Susilawati et al. (2013) showed that the use of peatland must be the right technology so that it does not damage the environment, the efforts made are giving manure or compost ameliorant. Ameliorant application on peatland can reduc CO2 emissions $32.23 \%$ (Hendri et al., 2017). Tangkit pineapple has been developed 65 ha on peatland in East Tanjung Jabung Regency from 2016-2018 and and will increase in 2019.

The production of Paun pineapple can be increased by providing ameliorants as well as on Tangkit pineapple. The results of research by Hernita and Linda (2018), ameliorant in the form of manure or tankos can increased plant height $20 \%$ and production $33 \%$.

Paun pineapple was consumed fresh, also processed as candy, dodol and juice. Efforts to improve the quality of Paun pineapple will develope small industry processing pineapple as it has been developed in Tangkit Baru Village, Sungai Gelam District, Muaro Jambi Regency.

The sustainability of genetic resources Tangkit and Paun pineapple have been carrying out maintenance and development based on existing potential. The waste of pineapple (rotten fruit, fruit peel and leaves) can be used potentially as various products such as animal feed, solid and liquid compost and probiotics. Probiotics contain bacteria that are good for digestion of livestock, so that they can increase animal immunity and increase in meat every day.

The pineapple peel contains more phenolic contents than the flesh and the fibrous. These results show that pineapple and its active constituents may be used in future as antioxidative therapy and provides a valuable source of nutraceutical supplements (Rasheed et al., 2012).

\section{CONCLUSION}

Morphological characters of Tangkit pineapple weight is 1-1.5 kg and Paun pineapple is 3.5-9 kg with fresh sweetness and productivity of 13.5-17.34 tons/ha and 9.1-13 tons/ha respectively, potential for developed on the peatland of Jambi Province.

\section{REFERENCES}

Anonymous. 2013. Potensi Komoditas Unggulan dan Lokasi Pengembangannya. http.nav perencanaan.com. (diakses tanggal 13 Mei 2013).

Anonymous. 2018. The Biology of Ananas comosus var. comosus (Pineapple). Australian Government. Department of Health and Ageing. Office of the Gene Technology Regulator.

Asmaida dan Zarkasih. 2018. Income from pineapple farming in Tangkit Baru Village, District Sungai Gelam, Muara Jambo Regency (Written in Indonesian language). Jurnal Media Agribisnis Vol. 3:1 hal 39 47.

[Balitro] Balai Penelitian Tanaman Rempah dan Obat. Hasil Analisis Buah Nanas. 2013. Bogor.

Bartholomew, D.P.,Paull, R.E., Rohrbach, K.G. 2003. The pineapple: botany, production and uses. Bartholomew, D.P., Paull, 
R.E.,Rohrbach, K.G (eds). CABI Publishing, Wallingford,UK. pp 1-301.

[BPS] Badan Pusat Statistik Provinsi Jambi. 2013. Jambi dalam Angka. Badan Pusat Statistik. Jambi.

[BPS] Badan Pusat Statistik Kabupaten Tanjung Jabung Barat. 2018. Kabupaten Tanjung Jabung Barat dalam Angka 2018. 457 hal.

[Dispertan] Dinas Pertanian Tanaman Pangan Provinsi Jambi. 2010. Usulan Pelepasan Varietas Nanas Paun. UPTD BPSP Dinas Pertanian Tanaman Pangan Provinsi Jambi.

[Dispertan] Dinas Pertanian Tanaman Pangan Provinsi Jambi. 2013. Varietas Unggul Nasional Asal Provinsi Jambi. UPTD Balai Pengawasan dan Sertifikasi Perbenihan Tanaman.

Dwiyanto K dan B Setiadi. 2008. Plasma Nutfah dalam Pengelolaan Pemanfaatan dan Pelestarian Sumberdaya Genetik Pertanian. Komisi Nasional Plasma Nutfah. Jakarta.

Hadiati, S. dan Indriyani, N.L.P. 2008. Petunjuk Teknis Budidaya Nenas. Solok: Balai Penelitian Tanaman Buah Tropika. 24 hal.

Hendri, J., Lindayanti, D.Hernita dan Salwati. 2017. $\mathrm{CO}_{2}$ flux in peatlands planted with pineapples in Jambi (written in Indonesian language). Prosiding Kongres Nasional Perkumpulan Masyarakat Gambut Indonesia (HGI) ke VII dan Seminar Pengelolaan Lahan Sub-Optimal Secara Berkelanjutan. Balai Besar Penelitian Dan Pengembangan Sumberdaya Lahan Pertanian, Badan Penelitian dan Pengembangan Pertanian, Kementerian Pertanian. 45-52 p.

Hernita, D dan L. Yanti. 2018. The enhancement of Tangkit pineapple production with Ameliorants in Peatlands supporting Bioindustry agriculture (Written in Indonesian language) cit Hutahaean, L, Rubiyo R.Hendayana, Pertanian Bioindustri Solusi Pertanian Masa Depan. IAARD PRESS. 673 hal.

Hernita, D dan Salvia. 2018. Potential and Development of genetic resource of pineapple in Peatlands, Jambi Province (Written in Indonesian language). cit Alamsyah, T, A. Muharam, E. Widjaja, W. Siska dan R. Hendayana. Mengoptimalkan Pemanfaatan Sumber Daya Genetik Nusantara Tanaman dan Ternak Merespon Kebijakan Ketahanan Pangan. IAARD PRESS. 736 hal.

Hossain, M.F. Akhtar, S. Anwar, M. 2015. Nutritional Value and Medicinal Benefit of Pineapple. International Journal of Nutirition and Food Sciences. $4.44-88 \mathrm{p}$.

Kurniadinata, O. F., Poerwanto, R., \& Susila, A. D. 2018. The Determination of Phosphor Status in Leaf Tissues to Make a Fertilizer Recommendation and Predict Mangosteen Yield. Journal of Tropical Horticulture, 1(1), 7-9.

Lavlinesia, Rahim Syah, Emanauli, Viny Suwita. 2016. Development of Processing Technology of Tangkit Pineapple into Velva by Farmers and Women as home industry makers in the Tangkit Baru Village, Sungai Gelam District, Muaro Jambi Regency di Desa Tangkit Baru Kecamatan Sungai Gelam Kabupaten Muaro Jambi.(Written in Indonesian language). Jurnal Pengabdian pada Masyarakat. Volume 31 (3):75-78.

Nindita, A., Umam, C., Fatimah, S., \& Suwarno, F. 2018. The Study of Early Selection Method through Vigor and Viability Parameter in Citrus amblycarpa (Hassk) under Salinity and Drought Stress Condition. Journal of Tropical Horticulture, 1(1), 1-6.

Mukhlish, D. Hernita, Zarmeili, H. Rusdi, Hamzah, A.Subhan, Sartik, B. Mardhotillah. 2014. Usulan Indikasi Geografis Nanas Tangkit Baru. Badan Penelitian dan Pengembangan Daerah Provinsi Jambi. Jambi.

Nofriati, D, Lindayanti dan Masito. 2016. The development of pineapples in Tangkit towards sustainable integrated bioindustry sector (Written in Indonesian language). Disampaikan pada Seminar Nasional Dies Natalis ke-53 Fakultas Pertanian Universitas Sriwijaya, Palembang 14 September 2016.

Pemdes Tangkit Baru. 2018. Monografi Desa Tangkit Baru. Desa Tangkit Baru, Kecamatan Sungai Gelam Kabupaten Muaro Jambi.

Pusdatim [Pusat data dan Sistem Informasi Pertanian]. 2016. Outlook Komoditas Pertanian Sub Sektor Hortikultura Nanas. Sekretariat
Jenderal-Kementerian Pertanian. 69 hal.

Rasheed, AA, EI Cobham, M Zeighami, SP Ong. 2012. Extraction of phenolic compounds from pineapple fruit International Symposium on Processing \& Drying of Foods, Vegetables and Fruits. University of Nottingham, Malaysia Campus.

Sopiawati, T, H. L. Susilawati, A. Hervani, D. Nursyamsi, P. Setyanto dan Nurhayati. 2013. Effect of application of ameliorants to the reduction of $\mathrm{CO}_{2}$ gas emissionon oil palm plantations with intercropping in peatlands (written in Indonesian language). Prosiding Seminar Nasional Pengelolaan Lahan Gambut Berkelanjutan. Badan Penelitian dan Pengembangan Pertanian Kementerian Pertanian.

Subagyo, H. 1997. The potential of development and spatial planning for agriculture (Written in Indonesian language). Prosiding Simposium nasional dan Kongres VI persatuan Agronomi Indonesia. Jakarta, 25-27 Januari 1996.

Supriyanto, J., E. Salvia dan J. Bobihoe. 2015. Preservation of horticultural genetic resources in Tanjung Jabung Regency, Jambi Province (written in Indonesian language). Prosiding Seminar Nasional Pengembangan Sumber daya Genetik Pertanian "Potensi Sumber Daya Genetik Spesifik Lokasi Mendukung Ketahanan dan Swasembada Pangan Nasional. Bogor, 27 Mei 2015.

Susilawati H.L, J. Hendri, D Nursyamsi dan P. Setyanto. 2013. Effect of application of ameliorants to $\mathrm{CO}_{2}$ on smallholding palm plantations in Muara Jambi Regency, Jambi Province (Written in Indonesian language). Prosiding Seminar Nasional Pengelolaan Lahan Gambut Berkelanjutan. Badan Penelitian dan Pengembangan Pertanian Kementerian Pertanian.

Wijaya, A., I.P.G., K. Nugroho, D. Ardi S., A.S.Karama. 1992. Sumber Daya Lahan Rawa: Potensi, Keterbatasan dan Pemanfaatan. Dalam: Sutjipto,P dan Mahyudin Syam. (eds).Pengembangan Terpadu Pertanian Lahan Rawa Pasang Surut dan Lebak. Risalah Nasional Pengembangan Pertanian Lahan Rawa Pasang Surut dan Lebak. Bogor, 3-4 Maret 1992.

Yanti, L., D. Nofriati dan N. Asni. 2015. Prospect of pineapple-based bioindustry development in Tangkit Village, Jambi Province (Written in Indonesian language). In Hendayana, R., A. Basit, K.G.Mudiarta dan T.Alihaamsyah. Perspektif Pengembangan Model Pertanian Bioindustri. IAARD Press. Badan Penelitian dan Pengembangan Pertanian. Jakarta.

Yanti, L., D. Novfriati, N. Asni. 2017. Keragaan Teknologi Pasca Panen dan Pengolahan Nanas Tangkit Menuju Pertanian Bioindustri di Provinsi Jambi. Bunga Rampai Bioindustri, Balai Besar Pengkajian dan Pengembangan Teknologi Pertanian. Bogor. 